\title{
DESTRUCTION OF THE PRAIRIE FALCON AT CALGARY, ALBERTA
}

by Kevin van Tighem, 315 Sharon Ave. S.W., Calgary, Alberta

In Birds of Alberta (1966) by Salt and Wilk there is a statement which says that "... the Prairie Falcon seems to be holding its own better than many ather species of hawk." During the past two years several observations made by interested observers in the Calgary region have proven that there is by no means any reason for saying that the Prairie Falcon is faring well.

One eyrie at Bearspaw Reservoir, near Calgary, has been watched for several years by a small group of observers. In the period from 1963 to 1966 at least three Prairie Falcons were shot with .22 rifles by irresponsible people. In 1966 the falcons arrived and began frequenting the sandstone cliffs again, but early in the year the male was shot. After a few days a second tercel appeared and the pair successfully raised four young after a late nesting. In 1967 the birds arrived in March and were definitely established in the cliff area until well into April. At this time I saw several people in the area with guns and I was not surprised to find the tercel dead late in April. The falcon was soon joined by another male but in the middle of May the pair abandoned the site and have not been seen in the area since.

The majority of the falcons and other hawks killed in this area are shot in the early spring upon arriving. At this time the lake is still icebound and people can drive up from the city and cross on the ice to the cliff area. Another reason for the departure of the Prairie Falcons from the area is the increasing use by humans of the bay in which the cliffs are located. The cliffs are often explored by families and children who walk in from Calgary or come across the lake by motorboat or canoe. Although the eyrie itself is inaccessible the constant shouting and movement prevents the falcons from remaining on the ey for any length of time.

There are other nest sites in Calgary region besides this which faring poorly too. At Bighill Cr near Cochrane two pairs of Prai Falcons were found nesting in 19 One nest contained four downy your the other was destroyed by an egg lector. Ten occupied eyries under servation along the Bow River fr Calgary downstream were also affe ed by irresponsible people. At le six were eliminated by amateur e collectors or people with a mistal compassion for baby birds; the otl four contain from one to four you

The great part of the damage flicted upon the Prairie Falcon is . to people from the cities out for day or a weekend who have no inter in protecting natural beauty. Peo upon whose property falcons $n$ appear to be among the few who that once destroyed these things c never be replaced.

As the inventions of science ma man more destructive, the me notably affected birds are the rapt whosie territories are often large, production rates low and susceptibil to maltreatment high. Pesticides car infertility in eggs, pollution caus food sources to be poisoned a various new modes of transportati permit lawless and irresponsible peor to reach out into the more reme regions where they cause the greate harm. It seems strange that at a tir when the public is becoming more a more concerned about the preservati of our natural heritage, laws concer ing the shooting of hawks and the ce lection of their eggs and young shou so seldom be enforced. Until some $d$ gree of official concern appears the is still a chance that birds like $t$ Prairie Falcon and Peregrine Falc will follow the Passenger Pigeon. 